\title{
Proximate Composition and Microbial level Estimation of some selected roasted/fried food items sold along Nigeria roadsides
}

\section{Nworu, J. S; Chime, E. C, Edafiokena, A; Amitaye, A. N; Ovili, V. U; Kazeem, W. O; Anyichie, I. K and Amuka, J. 0}

School of Basic Science (Chemistry), Nigeria Maritime University, Okerenkoko, Delta State

*Corresponding Author: jerome.nworu@nmu.edu.ng

\section{Doi: 10.2478/mjhr-2021-0007}

\section{Abstract:}

The objective of this study was to determine the proximate and microbiological compositions of some food samples obtained at three different locations within Ibadan Metropolis, Nigeria from different local food vendors. The highest mean carbohydrate, crude protein, fat, moisture, total ash and crude fibre are $88.10 \pm 0.79 \%$ (Roasted Yam), $17.76 \pm 2.29 \%$ (Roasted Fish), $20.54 \pm 4.0 \%$ (Suya Meat), $20.27 \pm 11.43 \%$ (Roasted Plantain), $4.57 \pm 0.10 \%$ (as in Suya Meat) and $5.07 \pm 0.69$ (Roasted Plantain) respectively while the lowest mean carbohydrate, crude protein, fat, moisture, total ash and crude fibre are 49.14 $\pm 1.37 \%$ (as in Fried Bean Cake), $0.08 \pm 0.01 \%$ (Roasted Yam), $0.47 \pm 0.05 \%$ (Roasted Yam), $1.81 \pm 0.33$ (Roasted Fish), $1.37 \pm 0.12$ (Doughnut) and 0.16 $\pm 0.06 \%$ (Fried Bean Cake) for all the samples estimated. The highest mean heterotropic bacteria and fungi counts are $6.19 \times 10^{3} \mathrm{cfu} / \mathrm{ml}(\mathrm{Roasted}$ Yam) and $3.30 \times 10^{3} \mathrm{cfu} / \mathrm{ml}$ (Fried Bean Cake) respectively while the lowest mean heterotropic bacteria and fungi counts are $1.64 \times 10^{3} \mathrm{cfu} / \mathrm{ml}$ (Doughnut) and $1.08 \times$ $10^{3} \mathrm{cfu} / \mathrm{ml}$ (Roasted Plantain) respectively. These food samples were shown to contain certain level of proximate parameters but these are not sufficient for nutritional requirements in human diet. Increasing the shelf-life of foods is one of the major purposes in food processing. Processes which precede food processing causes loss of essential vitamins and minerals. Also, roasted foods sold along Nigerian road-sides are exposed to dust accumulation and wastes from automobile exhaust.

Keywords: Proximate, Moisture, Ash content, Crude fibre, Crude Protein, Microbial

\subsection{Introduction}

Consumer trends and demands, national and international regulations, and the food industry's need to manage product quality dictate the need for analysis of food items. Food is one of the basic needs of life. It is essential for perfect health, productivity and mental development. Astronomical increase in population of developing countries has resulted in increase in food prices as well as shortage of fertile land which has resulted in hunger and malnutrition [1-2]. The importance of food in human existence cannot be over emphasize. This is the reason why issues of food and nutrition has been a major topical issues across the world especially in developing countries. It was estimated that 204 million people principally in sub-saharan Africa were severely malnourished between 1990 and 1992 as reported by the Food and Agricultural Organization (FAO) of the World Health Organization (WHO) [3]. This is mainly due to insufficient protein intake among the populace which has posed a major health concern especially in little children [4]. However, this malnutrition cannot be said to be principally caused by insufficient food intake but also of inadequate nutritional quality of the food available to the populace $[4,6]$. This might largely be due to the method of food processing which could contribute to nutritional loss. Food processing which include sorting, grading, packaging, re-shaping and value addition is aimed at increasing the shelf-life of food. However, washing, peeling and blanching steps which precede food processing are responsible for loss of essential vitamins and minerals [7]. Processes that exposed foods to high levels of oxygen, light and heat such as frying, roasting, washing and drying causes great nutritional loss [5, 8]. It is instructive to note that the commonest food processing methods employed by locals in West Africa including Nigeria are boiling, frying, roasting, smoking and drying.

Boiling is a method of cooking that involves water and allowing the water to boil vigorously while roasting is a method of using uncovered pan in the absence of water to produce brownish exterior and moist-cooked interior. These processing methods are aimed at increasing the nutritional quality of food and decreasing anti-nutritional substances present in them $[9,10]$. However, nutritional qualities are also loss in the process. It was reported that extrusion cooking affected the nutrients especially the proximate composition of pigeon pea and unripe plantain blends [4] while boiling and drying of seeds of African bread-fruit resulted in percentage decrease in nutrients and vitamin A [3]. Proximate analysis is of key commercial concern as food-manufacturing companies need to ensure that their products meet the appropriate laws and legal declaration requirements as well as the safety aspects of the end products when released to the end consumer. To meet the industry-desired standards and be competitive on the market, food-manufacturing companies need to find and utilize in their workflow reliable analytics techniques to analyse the production alongside with the ongoing manufacturing process. Many urban dwellers obtain a significant portion of their diet from street foods which increase the street food demand in major cities [34]. The preparation and sale of street foods is an age-old activity and has reached new dimensions as a result of rapid urbanization [35]. The safety and shelf life of these street foods, some ready-to-eat, depend upon the interaction of chemical, physical and microbial factors [36]. Street foods are foods and beverages that are sold by street vendors or hawkers and the foods and beverages could be raw or cooked [37]. They include starchy samples of maize, cassava, rice, plantain and yam; legumes like cowpea and groundnut, vegetables like tomatoes, onions, pepper, carrots, pumpkin etc and animal protein like goat meat, beef and various types of fishes [38]. Street foods displayed can be contaminated easily by dust, exhaust, smoke, insects, hands of intending buyers and climatic elements [35].

Street food vending is a large source of employment in many cities of developing countries [40], contributing significantly to household incomes [39]. Street vendors are often poorly educated, unlicenced, untrained in food hygiene practices and they work under unsanitary conditions with little or no knowledge about the causes of food borne diseases [41]. Most of the foods are not protected from flies which may carry food borne pathogens like Bacillus $s p$, Staphylococcus sp, E. coli, Clostridium sp, Vibrio sp, Campylobacter sp, Listeria sp and Salmonella sp [41,42]. Roasting and frying of foods (such as yam, potato, plantain, corn, fish and meat) are common delicacies among the people of Nigeria. It is common to find these delicacies at every nooks and crannies of the country. Locals patronize these delicacies almost on a daily basis. Yam tubers (Dioscorea sagittifolia), maize (Zea mays), plantain (Musa paradisiaca) and potato (Solanum tuberosum) are very good source of carbohydrates and are used as staple food while fish and meat are good source of protein. Effect of various cooking techniques have been observed on the proximate properties and/or chemical compositions of asparagus beans [11], Sorghum [21], Bambara Groundnut [20], Pigeon Pea [19], Common Bean (Phaseolus Vulagaris L.) [18], Frozen Leguminous Vegetables [17], Moin-moin [14, 16], Moinmoin and Akara from nucuna prurient [15], Wheat and Sesame seed flower blends [13], Wheat flour [12], Peanut and Sesame seed [10]. A critical search of the literature shows that there is no information on the level of proximate composition and microbial loads of roasted plantain, roasted fish, roasted yam, suya meat, fried potato, roasted corn, fried bean cake and doughnut even though these food samples are consumed by most Nigerians. The present study is therefore aimed at examining the nutritional qualities (proximate composition) and the microbial loads these street foods samples. 


\subsection{Materials and Methods}

\subsection{Sample collection}

Eight (8) different samples; Roasted plantain, Roasted Fish, Roasted Yam, Suya Meat, Fried potato, Roasted Corn, Fried beans cake and Doughnut were collected from three (3) different locations; Agbowo, Dugbe and Eleyele within Ibadan Metropolis, Nigeria from different local food vendors and stored in different sample bottles.

\subsection{Proximate Analysis}

\subsubsection{Moisture Content}

The amount of moisture in the food samples was determined according to AOAC [22]. Samples were dried in an air oven at $101^{\circ} \mathrm{C}$ for about 10 hours until constant weights were obtained, cooled in a desiccator, and reweighed. Moisture content was taken to be the differential between fresh and dry weights

\begin{tabular}{|c|c|c|c|c|c|c|c|c|c|c|}
\hline $\begin{array}{l}\text { Proximate } \\
\text { Analysis }\end{array}$ & Location & $\begin{array}{l}\text { Units } \\
(\%)\end{array}$ & $\mathbf{R P}$ & $\mathbf{R F}$ & RY & SM & FP & RC & FBC & DT \\
\hline & Agbowo & & & & & & & & & \\
\hline Carbohydrate & & & 79.76 & 74.05 & 88.99 & 50.51 & 59.11 & 79.58 & 50.21 & 64.61 \\
\hline Crude Protein & & & 3.65 & 15.89 & 0.085 & 8.50 & 10.03 & 7.12 & 12.03 & 8.02 \\
\hline Fat & & & 0.49 & 5.17 & 1.48 & 24.55 & 13.94 & 2.02 & 18.92 & 8.93 \\
\hline Moisture & & & 7.23 & 2.09 & 7.25 & 5.78 & 14.39 & 7.02 & 16.02 & 16.75 \\
\hline Total Ash & & & 3.31 & 1.70 & 1.45 & 4.45 & 2.02 & 2.05 & 2.60 & 1.27 \\
\hline \multirow[t]{2}{*}{ Crude Fiber } & & & 5.66 & 1.31 & 0.75 & 6.20 & 0.51 & 2.21 & 0.22 & 0.42 \\
\hline & Dugbe & & & & & & & & & \\
\hline Carbohydrate & & & 63.57 & 70.95 & 87.45 & 54.33 & 60.13 & 79.76 & 47.60 & 65.14 \\
\hline Crude Protein & & & 3.51 & 17.08 & 0.081 & 9.50 & 9.88 & 7.05 & 11.57 & 8.10 \\
\hline Fat & & & 0.40 & 6.78 & 2.48 & 20.51 & 12.51 & 1.54 & 22.09 & 9.91 \\
\hline Moisture & & & 25.03 & 1.90 & 7.90 & 4.81 & 15.05 & 7.43 & 15.98 & 14.83 \\
\hline Total Ash & & & 3.17 & 1.89 & 1.41 & 4.65 & 1.97 & 2.12 & 2.59 & 1.51 \\
\hline \multirow[t]{2}{*}{ Crude Fiber } & & & 4.32 & 1.40 & 0.68 & 6.20 & 0.46 & 2.10 & 0.17 & 0.51 \\
\hline & Eleyele & & & & & & & & & \\
\hline Carbohydrate & & & 59.27 & 70.03 & 87.85 & 57.64 & 60.53 & 79.79 & 49.62 & 65.0 \\
\hline Crude Protein & & & 3.40 & 20.31 & 0.078 & 8.5 & 10.01 & 6.98 & 12.31 & 7.87 \\
\hline Fat & & & 0.51 & 5.65 & 1.77 & 16.55 & 13.02 & 1.71 & 20.51 & 10.06 \\
\hline Moisture & & & 28.56 & 1.45 & 8.11 & 5.86 & 13.98 & 7.34 & 14.99 & 15.10 \\
\hline Total Ash & & & 3.02 & 1.15 & 1.50 & 4.60 & 2.08 & 2.11 & 2.47 & 1.34 \\
\hline Crude Fiber & & & 5.24 & 1.41 & 0.69 & 6.85 & 0.38 & 2.07 & 0.10 & 0.63 \\
\hline
\end{tabular}

\subsubsection{Ash Content}

Dried samples obtained in the process of moisture content determination were heated in a muffle furnace at $550^{\circ} \mathrm{C}$ for several hours. The percentage of ash was calculated by subtracting the weight of ash from the initial weight [22].

\subsubsection{Crude Protein Content and Carbohydrate}

Crude protein was analyzed by the Kjeldahl method [22]. The samples went through the three essential steps of digestion, distillation, and titration using a conversion factor of 6.25 to convert total nitrogen to crude protein. The percentage of protein in the samples was calculated thereafter. Subtracting the sum of fat content, protein content, ash content, and moisture from 100 gave the total carbohydrate content [23].

\subsubsection{Fat Content}

Crude fat was determined by weighing $5 \mathrm{~g}$ of each sample wrapped in a filter paper in a Soxhlet apparatus using petroleum ether. This was done each for 4 hours. The extracted materials left after the solvent had evaporated were weighed, and the fat content was calculated.

\subsection{Results and Discussions}

Eight (8) different samples; Roasted plantain, Roasted Fish, Roasted Yam, Suya Meat, Fried potato, Roasted Corn, Fried beans cake and Doughnut were collected from three (3) different locations; Agbowo, Dugbe and Eleyele within Ibadan Metropolis, Nigeria. The moisture content ranged from 1.90 - 28.56 $\% \mathrm{w} / \mathrm{w}$ in all the 8 fried samples. Roasted plantain had the highest moisture content $28.56 \% \mathrm{w} / \mathrm{w}$ while roasted fish had the lowest moisture content 1.45 $\% \mathrm{w} / \mathrm{w}$ purchased from all locations. There is no significant difference in the moisture content of all these fried samples. Moisture content which is the percentage composition of water in food samples is pertinent in human diet because it regulates the body temperature and it gives account on the shelf life of food samples, the higher the moisture contents the lower the shelf life.

Table 1. Proximate Composition of some selected fast foods within Ibadan Metropolis

\begin{tabular}{|c|c|c|c|c|c|c|}
\hline \multirow[t]{2}{*}{ Food items } & \multicolumn{6}{|c|}{ Proximate Composition } \\
\hline & Carbohydrate & Crude Protein & Fat & Moisture & Total Ash & Crude Fiber \\
\hline & Mean \pm SD & Mean \pm SD & Mean \pm SD & Mean \pm SD & Mean \pm SD & Mean \pm SD \\
\hline Roasted Plantain & $67.53 \pm 10.80$ & $3.52 \pm 0.13$ & $0.47 \pm 0.05$ & $20.27 \pm 11.43$ & $3.17 \pm 0.15$ & $5.07 \pm 0.69$ \\
\hline Roasted Fish & $71.68 \pm 2.11$ & $17.76 \pm 2.29$ & $5.87 \pm 0.83$ & $1.81 \pm 0.33$ & $1.58 \pm 0.38$ & $1.37 \pm 0.06$ \\
\hline Roasted Yam & $88.10 \pm 0.79$ & $0.08 \pm 0.01$ & $1.91 \pm 0.51$ & $7.75 \pm 0.45$ & $1.45 \pm 0.05$ & $0.71 \pm 0.04$ \\
\hline
\end{tabular}




\begin{tabular}{llllcc} 
Suya Meat & $54.16 \pm 3.57$ & $8.83 \pm 0.58$ & $20.54 \pm 4.0$ & $5.48 \pm 0.58$ & $4.57 \pm 0.10$ \\
Fried potato & $59.92 \pm 0.73$ & $9.97 \pm 0.08$ & $13.16 \pm 0.72$ & $14.47 \pm 0.54$ & $2.02 \pm 0.06$ \\
Roasted Corn & $79.71 \pm 0.11$ & $7.05 \pm 0.07$ & $1.75 \pm 0.24$ & $7.26 \pm 0.22$ & $2.09 \pm 0.04$ \\
Fried beans cake & $49.14 \pm 1.37$ & $11.97 \pm 0.37$ & $20.51 \pm 1.59$ & $15.66 \pm 0.58$ & $2.12 \pm 0.07$ \\
Doughnut & $64.92 \pm 0.27$ & $7.80 \pm 0.12$ & $9.63 \pm 0.61$ & $15.56 \pm 1.03$ & $1.37 \pm 0.12$ \\
\hline
\end{tabular}

The protein content ranged from $0.078-20.31 \% \mathrm{w} / \mathrm{w}$ with roasted yam having the lowest protein content $0.078 \% \mathrm{w} / \mathrm{w}$ and roasted fish having the highest protein content $20.31 \% \mathrm{w} / \mathrm{w} .7$ of the 8 food samples are protein-rich while the remaining is carbohydrate-rich. Roasted yam is the carbohydraterich food sample, and it is expected to have a low protein content. The result of this research prove this to be true with mean protein concentration of 0.08 $\pm 0.01 \% \mathrm{w} / \mathrm{w}$. Roasted fish is the richest in protein with a mean protein concentration of $17.76 \pm 2.29 \% \mathrm{w} / \mathrm{w}$, this is because its major ingredient is fish, which is a good source of protein. World health Organization $[24,25]$ estimated the average daily protein requirement for adult to be $52.5 \mathrm{~g}$, however, the amount of protein derivable from these roasted food samples were estimated at $0.078-20.31 \mathrm{~g} / 100 \mathrm{~g}$. The implication of this is that consumption of these fried food samples without any other protein supplements will be grossly inadequate to meet the significant role of protein in human diet. These fried food samples are not a good source of protein as a result of roasting which reduces the amount of protein content in these food samples. Protein is very important for the body growth and cell differentiation.

\begin{tabular}{|c|c|c|c|c|c|c|c|c|c|c|}
\hline MHA & Location & $\begin{array}{l}\text { Units } \\
\text { cfu/ml (x } \\
\left.10^{3}\right)\end{array}$ & $\mathbf{R P}$ & $\mathbf{R F}$ & $\mathbf{R Y}$ & SM & FP & RC & FBC & DN \\
\hline & Agbowo & & & & & & & & & \\
\hline ТнB & & & 1.55 & 5.88 & 2.01 & 4.77 & 3.00 & 2.88 & 4.00 & 1.11 \\
\hline \multirow[t]{2}{*}{ THF } & & & 1.00 & 2.11 & 1.00 & 2.00 & 3.22 & 1.00 & 4.00 & 2.80 \\
\hline & Dugbe & & & & & & & & & \\
\hline ТHB & & & 2.00 & 6.70 & 2.11 & 3.88 & 2.50 & 3.21 & 3.55 & 1.82 \\
\hline \multirow[t]{2}{*}{ THF } & & & 1.00 & 2.66 & 2.17 & 1.05 & 2.55 & 1.88 & 3.25 & 2.11 \\
\hline & Eleyele & & & & & & & & & \\
\hline THB & & & 2.22 & 6.00 & 1.92 & 3.00 & 2.56 & 2.31 & 2.11 & 1.98 \\
\hline THF & & & 1.23 & 2.96 & 2.44 & 2.00 & 3.11 & 1.24 & 2.66 & 2.11 \\
\hline
\end{tabular}

According to Schmid [26], fats contribute to the absorption of fat-soluble vitamins, and acts as structural elements of cell walls, in addition to its being a concentrated source of energy. High intake of fats has associated risks such as obesity, type 2 diabetes, cancer, and coronary heart disease. The fat content ranged from $0.40-22.09 \% \mathrm{w} / \mathrm{w}$ in all the 8 food samples. In all locations, roasted plantain and roasted yam have the lowest mean fat content with values being at $0.47 \pm 0.05 \% \mathrm{w} / \mathrm{w}$ and $1.91 \pm 0.51 \% \mathrm{w} / \mathrm{w}$ respectively while suya meat and fried beans cake had the highest mean fat concentration at $20.54 \pm$ $4.0 \% \mathrm{w} / \mathrm{w}$ and $20.51 \pm 1.59 \% \mathrm{w} / \mathrm{w}$ respectively. Akara (fried beans cake) is popular food in Nigeria and other West African Countries [27, 30, 32] and form part of diet for most ethnic groups in Nigeria. Beans are about 2 to 3 percent fat and contain no cholesterol unless they are processed or prepared with other ingredients. This shows that other ingredients have been prepared with the fried beans cake resulting in its high fat contents. It is not surprising that suya meat is relatively high in fat contents as high intake of animal fats often result in obesity, cancer and coronary heart disease.

Carbohydrates are the body's main source of energy and they comprise 40-80 \% of total food energy intake. The carbohydrate content ranged from 50.51 $-88.99 \% \mathrm{w} / \mathrm{w}$. Roasted yam has the highest mean carbohydrate content $88.10 \pm 0.79 \% \mathrm{w} / \mathrm{w}$ while suya meat had the lowest mean carbohydrate content $54.16 \pm 3.57 \% \mathrm{w} / \mathrm{w}$. FAO [31] also estimated fresh raw plantain to contain high carbohydrate content which is about $32 \mathrm{~g} / 100 \mathrm{~g}$. The result above also showed roasted plantain to contain high carbohydrate content $67.53 \pm 10.80 \% \mathrm{w} / \mathrm{w}$. The ash content of a feedstuff is the inorganic residue remaining after the organic matter has been destroyed by combustion in the muffle furnace $[5,22,29]$. The ash content of the fried food samples ranged from $1.37-3.17$ $\% \mathrm{w} / \mathrm{w}$ with roasted plantain having the highest ash content while doughnut had the lowest mean ash content. Roasted plantain having the highest ash content is in alignment with the result of [28] who obtained a mean ash content $5.15 \mathrm{~g} / 100 \mathrm{~g}$ in roasted plantain from all locations. Roasted plantain had the highest percentage crude fibre of $5.07 \% \mathrm{w} / \mathrm{w}$. The percentage compositions of crude fibre in the roasted food samples ranged from $0.16 \%-5.07 \%$ with fried beans cake having the least percentage composition.

Table 2. Microbiological Hazard Anlysis of the selected fast foods

\begin{tabular}{llc}
\hline Food items & & Proximate Composition \\
\hline & THB & THF \\
Roasted Plantain (RP) & 1.92 & 1.08 \\
Roasted Fish (RF) & 6.19 & 2.58 \\
Roasted Yam (RY) & 2.01 & 1.87 \\
Suya Meat (SM) & 3.88 & 1.68 \\
Fried potato (FP) & 2.69 & 2.96 \\
Roasted Corn (RC) & 2.80 & 1.37 \\
Fried beans cake (FBC) & 3.22 & 3.30 \\
Doughnut (DN) & 1.64 & 2.34 \\
\hline
\end{tabular}

THF $=$ Total Heterotrophic Fungi, THB = Total Heterotrophic Bacteria

Reports $[28,33]$ found out that several microorganisms such as fecal coliform bacteria, Salmonella species etc which have public health concern have been implicated in street foods sold in some African countries. These street foods include meat/ fish pies, moin-moin, and roasted food items which is the focal point of our research. The above table 2 showed that roasted fish has the highest mean heterotrophic bacteria count $6.19 \times 10^{3} \mathrm{cfu} / \mathrm{ml}$, followed by suya meat $3.88 \times 10^{3} \mathrm{cfu} / \mathrm{ml}$ while doughnut has the lowest mean heterotrophic bacteria count $1.64 \times 10^{3} \mathrm{cfu} / \mathrm{ml}$. The table also showed that fried beans cake has the highest mean heterotrophic fungi count $3.30 \times 10^{3} \mathrm{cfu} / \mathrm{ml}$, followed by fried potato $2.96 \times 10^{3} \mathrm{cfu} / \mathrm{ml}$ while roasted plantain has the lowest mean heterotrophic fungi count $1.08 \times 10^{3} \mathrm{cfu} / \mathrm{ml}$. The WHO standards for Total heterotrophic bacteria (THB) count is $10-16 \mathrm{cfu} / \mathrm{ml}$ of which the microbial 
loads of the roasted food items were far higher than the standards. These high bacteria count could be as a result of the food items being processed with water from sources that are not treated [28]. Presence of bacteria and fungi in high amount in these roasted food items could pose health risk to the consumers. Factors that could have contributed to the high bacteria and fungi counts are as follows; exposure of raw and roasted food items to the environment, poor hygienic practice such as inadequate washing of hands and utensils and poor food preparation handling

\subsection{Conclusion}

These fried food samples are sources of affordable nutrients. The result indicated that roasted yam had the highest carbohydrate content while fried beans cake had the lowest carbohydrate content, while roasted fish is the richest in crude protein content roasted yam is the least in crude protein content. The result also showed that suya meat had the highest fat content with roasted corn having the least fat content, and also roasted plantain had the highest moisture content while roasted fish had the lowest moisture content. Roasted plantain had the highest ash content and crude fibre content with doughnut and fried beans having the lowest ash content and fibre content respectively. While these fried food samples contain all the nutrients, they do not provide sufficient nutrients and therefore it is recommended that they should be taken with other food items in order to adequately meet the significant role of carbohydrate, protein, fat and fibre in human diet.

\subsection{References}

[1] C. Hotz and R.S. Gibson, "Traditional Food-Processing and Preparation Practices to Enhance the Bioavailability of Micronutrients in Plant-Based Diets", The Journal of Nutrition. Vol. 137, Pp. 1097-1100, 2007.

[2] N. Khan, B. Ruqia, J. Hussain, N. Jamila, N.U. Rehman and S.T. Hussain, "Nutritional Assessment and Proximate Analysis of Selected Vegetables from Parachinar Kurram Agency Nutritional Assessment and Proximate Analysis of Selected Vegetables from Parachinar Kurram Agency", American Journal of Research Communication, Vol. 1, No. 8, Pp. 194-198, 2013.

[3] I.I. Ijeh, C.E. Ejike, O.M. Nkwonta, and B.C. Njoku, "Effect of Traditional Processing Techniques on the Nutritional and Phytochemical Composition of African Bread-Fruit ( Treculia Africana ) Seeds", J. Appl. Sci. Environ. Manage., Vol. 14, No. 14, Pp. 169-173, 2010.

[4] J.C. Anuonye, A.A. Jigam and G.M. Ndaceko, "Effects of Extrusion-Cooking on the Nutrient and Anti-Nutrient Composition of Pigeon Pea and Unripe Plantain Blends", Journal of Applied Pharmaceutical Science, Vol. 2 (5), Pp. 158-62, 2012.

[5] AOAC, Official Method of Analysis. 15 ${ }^{\text {th }}$ Edn. “Washington DC Association of Official Analytical Chemists", 1990.

[6] C. Hotz and R.S. Gibson, "Traditional Food-Processing and Preparation Practices to Enhance the Bioavailability of Micronutrients in Plant-Based Diets", The Journal of Nutrition. Vol 137, Pp. 1097-1100, 2007.

[7] J.C. Rickman., D.M. Barrett and C.M. Bruhn, "Nutritional Comparison of Fresh , Frozen and Canned Fruits and Vegetables", Part 1. Vitamins C and B and Phenolic Compounds. J of the Sci Food Agric. Vol. 87, Pp. 930-44.

[8] R. Devi, “Food Processing and Impact on Nutrition”, Sch. J. Agric. Vet. Sci., Vol. 2, Pp. 304-11, 2015.

[9] F.I. Nwafor, S.N. Egonu, N.O. Nweze, and S.N. Ohabuenyi, "Effect of Processing Methods on the Nutritional Values and Anti-Nutritive Factors of Adenanthera Pavonina L. ( Fabaceae ) Seeds", African Journal of Biotechnology., Vol. 16, No. 3, Pp. 106-112, 2017.

[10] C.E. Hassan, "Effect of heat treatments on certain ant-nutrients and in vitro protein digestibility of peanut and sesame seeds", Food Science Technology Review, Vol. 17, No. 1, Pp. 31-38, 2011.

[11] D. Nzewi and A. Egbuonu, "Effect of boiling and washing on the proximate properties of asparagus been (Vigna Sesquipedahs)", African Journal of Biotechnology, Vol. 10, No. 54, Pp. 1123-1124, 2011.

[12] S. Akhtar, F. Anjum, S. Rehman, M. Sheikh and K. Farzena, "Physico-chemical and microbiological stability of whole wheat flour", Food Chem., Vol. 112, Pp. 156-163, 2008.

[13] O.M. Akusu, D.B. Kiin-Kabari, and E.M. Isah, 2019. Effects of processing methods on the nutrient composition and Sensory attributes of cookies produced from wheat and sesame seed flour blends. International Journal of Nutritional, Science and Food Tech., Vol. 5, Pp. 34-40.

[14] R.A. Mustapha, G.A. Ogundahunsi, O.I. Olanrewaju, and O.O. Bolajoko, "Effect of Processing Materials on Nutrients, Phytochemicals and Sensory Attributes of Moinmoin", Nigeria Journal of Nutritional Science, Vol. 35, No. 1, Pp. 97-103, 2016.

[15] T.S. Asogwa, and J.C. Onweluze, "Effect of processing methods on the chemical composition of flour, "moinmoin" and Akara from nucuna prurient", J. of Tropical Agriculture, Food, Environment and Extension, Vol. 9, No. 3, Pp. 200-208, 2010.

[16] T.A. Aniebet and O.I. Olanrewaju, "Nutrients, Phytochemical's composition of Moinmoin made from different varieties of leguminous plants. IOSR Journal of Pharmacy and Biological Sciences (IOSR-JPBS). Vol. 13, Pp. 05-10, 2018.

[17] Z. Lisiewska, J. Slupski, W. Kmiecik and P. Gebczynski, "Availability of essential and trace elements in frozen Leguminous vegetable is prepared for consumption according to the method of pre-freezing processing", Food Chem., Vol. 106, Pp. 576-582, 2008.

[18] J. Slupski, "Effect of freezing and canning on the content of vitamin C in immature seeds of five cultivars of common bean (Phaseolus Vulgaris L.)", Acta. Sci. Pol. Technol. Aliment., Vol. 10, No. 2, Pp. 197-208, 2011.

[19] E.C. Nwanekezi, F.N. Ehirim and D.C. Arukwe, "Combined effects of different processing methods on vitamins and anti-nutrients contents of Pigeon Pea (Cajanus cajan) flour", IOSR Journal of Environmental Science, Toxicology and Food Technology (IOSR-JESTFT), Vol. 11, Pp. 73-81, 2017.

[20] I.F. Fadahunsi, "The effect of soaking, boiling and fermentation with Rhizopus oligosporus on the water soluble vitamin content of Bambara Groundnut", Pakistan Journal of Nutrition, Vol. 8, Pp. 835-840, 2009.

[21] I.C. Obizoba and J.V. Ath, "Effect of soaking, sprouting, fermentation and cooking on the nutrient composition and some anti-nutritional factors of sorghum (Guinea) seeds", Plant Foods of Human Nutrition, Vol. 41, Pp. 203-212, 1991. 
[22] AOAC, Official Methods of Analysis of the Association of the Official Analytical Chemists, 17th edition, AOAC International, Washington, DC, USA, 2000.

[23] E.N. Onyeike, E.O. Ayoologu, and C.O. Ibegbulam, "Evaluation of the nutritional value of some crude oil in polluted freshwater fishes," Global Journal of Pure and Applied Sciences, Vol. 6, No. 2, Pp. 227-233, 2000.

[24] WHO, “Energy and protein requirements. Reports of a joint FAO/WHO/UNU expert consultation”, WHO technical report series, No 725. Geneva, 1985.

[25] World Health Organization. "Essential Safety Requirements for Street Vended Foods", Foods Safety Unit, Division of Food and Nutrition. WHO/FNUI/FOSF 96, 7, 1996.

[26] A. Schmid, "The role of meat fat in the human diet", Crit Rev Food Sci Nutr., Vol. 51, No. 1, Pp. 50 -66, 2011.

[27] P.O. Ngoddy, N.J. Enwere and V.I. Onurah, “Cowpea flour performance in Akara and moi-moi preparations”, Tropical science., Vol. 26, Pp. 101 - 119, 2019.

[28] H.D. Muinde and E. Kuria, "Hygienic and Sanitary practices of vendors of street foods in Nairobi, Kenya”, Afr. J. of Food, Agric. and Nutr. Dev., Vol. 5, Pp. $1-14,2015$

[29] MAFF (Ministry of Agriculture, Fisheries and Food). The analysis of a agriculture materials, RB427, Second Edition, HMSO, London, Pp. $22,2014$.

[30] F.O. Henshaw and S.A. Lawal, "Effects of processing methods on the functional properties cowpea flour", Journal of Tropical Science, Vol. 33, Pp. 377 $385,2018$.

[31] FAO, Carbohydrate in human nutrition. Report of a Joint FAO/WHO Expert Consultation. FAO Food and Nutrition. Paper No 66. Rome, 2000.

[32] P. Ekariko, "Akara: The Fast Food with a Painstaking Preparation”, Afriquie, Vol. 16, Pp. 14, 2015.

[33] S.C. Achinewhu and E.N. Amadi, "Bacterial Flora of Some Street Foods in Port Harcourt, Nigeria”, Nigeria Delta Biol., Vol. 1, Pp. 59 - 61, 2017.

[34] 0.0. Pikuda, and N.O.A. Ilelaboye, "Proximate composition of street snacks purchased from selected motor parks in Lagos", Pakistan Journal of Nutrition, Vol. 8, Pp. 1657-1660, 2019.

[35] C.C. Ike, P.C. Emeka-Ike, C.C. Nwokorie, and C.C. Anochie, "Microbiological Quality Evaluation of locally prepared snacks sold in Aba metropolis, Abia State, Nigeria", International Journal of Scientific Engineering and Applied Science, Vol. 1, Pp. 46-59, 2015.

[36] S. Oranusi, F. Omagbemi, and A.O. Eni, "Microbiological safety and evaluation of snacks sold in fast food shops in Ota, Ogun State, Nigeria", International Journal of Agricultural and Food Science, Vol. 1, Pp. 75- 79, 2019.

[37] E. Ameko, S. Achio, S. Alhassan, and A. Kassim, "Microbiology safety of raw mixed vegetable salad sold as an accompaniment to street vended cooked rice in Accra Ghana”, Afr. J. Biotechnol., Vol. 11, Pp. 11078-11085, 2018.

[38] M. Choudhury, L. Mahanta, J. Goswani, M. Mazumder, and B. Pegoo, "Socioeconomic profile and food safety knowledge and practice of street food vendors in the city of Guwahati, Assam, India", Food Control, Vol. 22, Pp. 196-203, 2018.

[39] P. Feglo, and K. Sakyi, "Bacterial contamination of street vending food in Kumasi, Ghana”, Journal of Medical and Biomedical Science, Vol. 1, Pp. 1-8, 2012.

[40] N. Barro, A.R. Bello, Y. Itsiembou, A. Savadogo, and C.A.T. Ouattara, "Street vended foods improvement: contamination mechanisms and applications of food safety objective strategy", Critical Review, Vol. 6, Pp. 01-10, 2017.

[41] F.I. Akinnibosun, and P. Airiohuodion, "Microbial assessment and proximate analysis of popcorn sold along Benin - Sapele expressway, Nigeria", J. Chem. Biol. Phys. Sci., Vol. 5, Pp. 1711-1718, 2018.

[42] N.N. Odu, and L.N. Imaku, "Assessment of the microbiological quality of street - vended ready-to-eat bole (roasted plantain) fish (Trachurus trachurus) in Port Harcourt metropolis, Nigeria", Researcher, Vol. 5, Pp. 9-18, 2019. 